\title{
Quality and Sensory Comparison of Ostrich and Goat Meat
}

\author{
Muhammad Bilal Akram ${ }^{1}$, Muhammad Issa Khan ${ }^{2 *}$, Shahiryar Khalid ${ }^{1}$, Muhammad Shoaib ${ }^{3}$, Syeda Azeema \\ Hassan $^{1}$
}

${ }^{1}$ Student, National Institute of food science and Technology, Faculty of Food Nutrition and Home Science, University of Agriculture, Faisalabad, Pakistan

${ }^{2}$ Associate Professor, National Institute of food science and Technology, Faculty of Food Nutrition and Home Science, University of Agriculture, Faisalabad, Pakistan

${ }^{3}$ Student, Institute of Microbiology, University of Agriculture, Faisalabad, Pakistan

\begin{abstract}
*Address for Correspondence: Dr. Muhammad Issa Khan, Associate Professor, National Institute of food science and Technology, Faculty of Food Nutrition and Home Science, University of Agriculture, Faisalabad, Pakistan
\end{abstract}

E-mail: $\underline{\text { drkhan@@uaf.edu.pk }}$

Received: 26 Sep 2018/ Revised: 20 Nov 2018/ Accepted: 29 Dec 2018

\begin{abstract}
Background: Meat is an animal flesh and good source of protein in human diet. Poultry production has increased in the world owing to consumer's demand resulting in decreased consumption of red meat. Major issues with consumption of red meat are higher cholesterol level, cardiovascular diseases, artheoseclorosis and other health threatening problems. Issues related to red meat can be solved by consumption of ostrich meat that is recognized as healthy. In the poultry industry ostrich farming is an innovative turn and can provide a new taste in the food industry.

Methods: For this purpose, comparative study of ostrich and goat meat was carried out National Institute of Food Science and Technology from March to September 2018. The objective was to study proximate composition, physico-chemical characteristic and sensory evaluation of ostrich and goat meat.

Results: The result indicated that ostrich meat shows higher moisture content, higher protein content and higher ash content as compared to goat meat. Fat content was low in ostrich meat as compared to goat meat. Water holding capacity, collagen content was high in ostrich meat as compared to goat meat. Ostrich meat shows dark red cherry color as compared to goat meat and show high myoglobin as compared to goat meat. Sensory evaluation of ostrich meat gains highly acceptable score as compared to goat meat.

Conclusion: The present study indicated that ostrich meat was more acceptable as compared to goat meat. So, it would be recommended for those consumer that having high cholesterol, cardiovascular diseases and other such diseases. Ostrich meat is overall good for everyone, good for health without any life threatening.
\end{abstract}

Key-words: Goat meat, Ostrichmeat, Physico-chemical characteristic, Proximate analysis, Sensory evaluation

\section{INTRODUCTION}

Meat is flesh of an animal that is used as food that provides us nutrients like carbohydrates, protein, fat, vitamin and mineral; these nutrients provide us with energy for maintenance requirement and building blocks of the body. In Pakistan, a bulk of meat consumed comes from the cattle, lamb, goat and poultry. Estimated 4061

\section{How to cite this article}

Akram MB, Khan MI, Khalid S, Shoaib M, Hassan SA. Quality and Sensory Comparison of Ostrich and Goat Meat. SSR Inst. Int. J. Life. Sci., 2019; 5(1): 2168-2175.

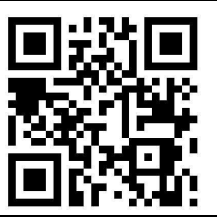

metric ton is total meat production of Pakistan and mutton is 701 metric ton and not yet mentioned ostrich meat production ina survey by livestock sector because ostrich farming is new meat production idea in Pakistan therefore, there production is not mentioned yet ${ }^{[1]}$. White meat production has increased last decade in the world due to consumer demand resulting in decreased consumption of red meat. A major issue with consumption of red meat was increased cholesterol level, cardiovascular disease, artheoseclorosis and another such disease that cause a health problem. Therefore, white meat gains number one priority in the world ${ }^{[2]}$. Issues related with red meat might be solving by consumption of ostrich meat comparative to goat meat that recognizes as healthy, whereas $60 \%$ of the 
world population in developing countries has an animal protein deficiency. Nutritionally in animal meat has some important fats, amino acid and other micronutrients. When animal protein is compared with plant protein it is considered that animal protein is better than plant based protein. Ostrich is a flightless bird native to South Africa. In $19^{\text {th }}$ century ostrich feather was used as a fashion and no one now real objective of ostrich meat and their products ${ }^{[3]}$. More than $60 \%$ human population is present in Asia; huge dis-similarities are existing in them on the basis of belief, providence, medium and history. Therefore, ostrich meat consumption is different in such basis and day by day meat industry increased. Ostrich meat also contains omega- 3 fatty acid and omega- 6 fatty acid content that play an important role in the body. Omega-3 fatty acid is essential for growth and development of man and also reduces coronary diseases ${ }^{[4]}$. Ostrich meat has $\mathrm{pH}$ greater than 6.0 that is favorable for color and water holding capacity. Meat quality is one of important key factor that effect meat acceptability and rejects ability in which lipid peroxidation is one important parameter. Lipid peroxidation reduced meat freshness and cause meat muscle color change. Goat meat is also a rich source of protein. Goat productions are spread throughout the world with increasing desire for meat, milk and skin ${ }^{[5]}$. On commercial scale, small ruminants are producing for two purposes, milk production and meat production ${ }^{[6,7]}$. Red meat quality depends on age factor and invariable acceptance range varies from 2-6 incisor of goat meat ${ }^{[8]}$. Various elements determine information about consumer preference during meat purchasing but the quality of meat is more significance. In the modern era, consumer preference toward healthy food is more crucial; especially fatty acid composition and fat content are an important factor that interlinked with healthiness of meat. Therefore, an objective of this study is to evaluate quality and sensory acceptability of ostrich meat in comparison to goat meat.

\section{MATERIALS AND METHODS}

Procurement of raw material- Ostrich meat was procured from Signature Meat Shop, Lahore and Goat meat was procured from Al-Fatah store and shifted to Meat Science and Technology Laboratory at National Institute of Food Science and Technology in University of Agriculture, Faisalabad, Pakistan for analytical study from March to September 2018. Bone, connective tissue, fat was removed from ostrich and goat meat on arrival to laboratory. After that ostrich and goat meat were stored at $-40^{\circ} \mathrm{C}$ and then required sample was used for quality, chemical analysis and sensorial evaluation. All analysis was conduct in triplicate.

Chemical analysis- Moisture, fat, protein and ash content of ostrich and goat meat was determined as a method described by AOAC ${ }^{[9]}$. Moisture content (g water/100 g) was determined by placed sample in an oven at $105 \pm 5^{\circ} \mathrm{C}$ for 18 hours or until constant weigh. Moisture free sample was used for determination of fat content (g fat/100 g) by using Soxhlet apparatus by placing sample in a flask at $60-80^{\circ} \mathrm{C}$. Moisture free sample was used for determination of the percentage of nitrogen in ostrich and goat meat sample by using kjeldhal apparatus. Nitrogen content was multiply with a constant factor for determination of protein content. Ash content of meat ( $\mathrm{g}$ ash/100 g) was determined by using moisture free sample in Muffle Furnace at $550-650^{\circ} \mathrm{C}$ for 3 - 4 hour.

\section{Physiochemical analysis}

$\mathrm{pH}$ - Total $10 \mathrm{~g}$ sample in $100 \mathrm{~mL}$ distilled water was taken to determined ostrich and goat meat $\mathrm{pH}$ by using the method described by Berge et al. ${ }^{[10]}$. After that $10 \mathrm{~g}$ minced meat sample was homogenized in $100 \mathrm{ml}$ distilled water for 30 second at high speed by using homogenizer. Later on $\mathrm{pH}$ meter was calibrated for $\mathrm{pH}$ determination by using $\mathrm{pH} \mathrm{4,} \mathrm{7,} 10$ standard buffers. For $\mathrm{pH}$ determination homogenized sample was taken into beaker by placing $\mathrm{pH}$ knob into sample and $\mathrm{pH}$ of ostrich was noted.

Color determination- Ground meat samples of ostrich and goat meat were taken and stored at $4^{\circ} \mathrm{C}$ for twenty minute for color determination. The objective of refrigeration was to enable myoglobin oxygenation on meat surface layer. Hunter Lab Scan XE apparatus was used for color measurement. Three reading per sample of ostrich and goat meat were taken for redness, lightness and yellowness as method described by Hunt et al. $^{[11]}$.

Water holding capacity- Water holding capacity of ostrich and goat meat was determined by drip loss and cooking loss method as method Honikel ${ }^{[12]}$. For determination of drip loss weight of six muscles about $1.5 \mathrm{~cm}$ thick were taken and sample were settled in rope and suspended in air tight plastic bag. Later on, $24 \mathrm{~h}$ 
storage at $4^{\circ} \mathrm{C}$ sample moisture was absorbed by using absorbent paper. Sample was re-weighted to determined drip loss of ostrich and goat meat. Similarly, water holding capacity of ostrich and goat meat was determined by cooking loss method as described by Honikel ${ }^{[12]}$. Approximately $1 \mathrm{~cm}$ thick six samples were weighed and settle in a thin plastic bag at $80^{\circ} \mathrm{C}$ in the water bath. After that samples were removed from water bath after one an hour. Later on samples were cooled in cold water and moisture absorb with the help of blotted paper. A sample was weighed after cooking loss.

Myoglobin and metmyoglobin- Myoglobin and metmyoglobin of ostrich and goat meat were determined by using UV-VIS spectrophotometer as a method described by Trout ${ }^{[13]}$. For determination of baseline, turn on spectrophotometer for $30 \mathrm{~min}$ so that it allows system to warm up and placed $1.0 \mathrm{ml}$ of $0.04 \mathrm{M}$ sodium phosphate buffer at $6.0 \mathrm{pH}$ as a blank sample was taken in to cuvette scan sample $450 \mathrm{~nm}$ to $650 \mathrm{~nm}$ to establish a baseline. For myoglobin determination, 25 g sample was taken and homogenized with $0.04 \mathrm{M}$ phosphate buffer solution at $\mathrm{pH} 6.8$ at high speed for 45 seconds in a homogenizer. UV-VIS spectrophotometer was used for filtrate absorbance at 700, 572 and $525 \mathrm{~nm}$. For metmyoglobin determination, 25 g sample was taken and homogenized with $0.04 \mathrm{M}$ phosphate buffer solution at $\mathrm{pH} 6.8$ at high speed for 45 second in a homogenizer. In both situations, Whatman no.1 filter paper was used for filtration. One $\mathrm{ml}$ filter sample was taken into cuvette and placed sample port in spectrophotometer. UV-VIS spectrophotometer was used for filtrate absorbance at $650 \mathrm{~nm}$ wavelength.

Collagen content- Collagen content of ostrich and goat meat was determined by using method of Naveena et al. ${ }^{[14]}$. Collagen content of ostrich and goat meat was determined by multiplying hydroxyproline content with 7.14 and collagen content of ostrich and goat meat was showed in mg/g. Hydroxyproline (HP) contents of ostrich and goat meat sample were evaluated by protocol as described by Naveena et al. ${ }^{[14]}$. Ostrich and goat sample was hydrolyzed with $40 \mathrm{ml} 6 \mathrm{~N} \mathrm{HCl}$ at $108^{\circ} \mathrm{C}$ for $18 \mathrm{~h}$. To $\mathrm{pH}$ of hydrolysate as fine turn at 7.0 and take $1 \mathrm{ml}$ of this solution for estimation of Hydroxyproline (HP) content. UV-VIS spectrophotometer was used for this purpose and measurement was done at $540 \mathrm{~nm}$ wavelength.
Texture analysis- Texture profile of ostrich and goat meat was determined by using texture analyzer as method described by Piga et al. ${ }^{[15]}$. Ostrich and goat sample were placed below the needle of texture analyzer. Amount of force applied by needle of texture analyzer was measured in a kilogram. Calculation of each sample was calculated at an internal temperature at 7 으 and needle speed of texture analyzer was set at 80 $\mathrm{mm} / \mathrm{min}$. Needle of texture analyzer was applied perpendicularly to the fiber direction of ostrich and goat meat. Texture analyzer basically gives information of tenderness of the meat. Therefore, by using texture analyzer tenderness of ostrich and goat meat was determined.

Mineral composition- Mineral composition of ostrich and goat meat was determined by using a wet method described by Sales and Hayes ${ }^{[16]}$. First of all meat $1 \mathrm{~g}$ sample taken in a beaker by adding $7 / 5 \mathrm{HON}_{3}$ and also adding $\mathrm{HClO}_{4}$ in it. Heat the sample on a hot plate by constant stirring until $2 \mathrm{ml}$ sample left. Dilute it up to 100 $\mathrm{ml}$ and filter store. Direct current plasma emission spectrometry was used for mineral composition of ostrich and goat meat.

Sensory evaluation- For sensory evaluation grilled meat sample of ostrich and goat meat was subjected for appearance, chewiness, juiciness, flavor and overall acceptability. A panel of five judges evaluated the sensory evaluation of ostrich and goat meat by using 9-point hedonic scale as method narrated by Meilgaard et al. ${ }^{[17]}$.

Statistical Analysis- Data obtained for each parameter was analyzed statistically using simple CRD to check the level of significance at alpha $5 \%$ Steel et al. ${ }^{[18]}$.

\section{RESULTS}

This research was formulated to assess and compare the physiochemical and functional properties of ostrich with goat meat. The present study helped out to understand ostrich meat with goat meat for better understanding and would be fruitful for further study.

Proximate analysis- Proximate analysis of ostrich and goat meat was determined and values are presented in Table 1. 
Table 1: Mean values for compositional analysis of Ostrich and Goat meat (Mean \pm SD), $n=3$

\begin{tabular}{ccc}
\hline Parameters (\%) & Ostrich (Mean \pm SD) & Goat (Mean \pm SD) \\
Moisture & $76.51 \pm 0.05$ & $75.71 \pm 0.01$ \\
Crude Protein & $21.18 \pm 0.06$ & $3.23 \pm 0.05$ \\
Crude Fat & $1.26 \pm 0.17$ & $1.07 \pm 0.01$ \\
Ash & $1.14 \pm 0.03$ & 3 \\
\hline
\end{tabular}

Quality analysis of ostrich and goat meat- Quality analysis of ostrich and goat meat were determined to check the quality parameter of ostrich and goat meat. For this color of ostrich meat was compared with goat meat as result shows in Table 2. Similarly $\mathrm{pH}$ of ostrich meat was compared with goat meat as showed in Table 3 because $\mathrm{pH}$ is basic parameter that effect meat quality. Water holding capacity of ostrich and goat meat was determined to check the meat quality as result shows in
Table 3. Myoglobin and metmyoglobin, collagen content, Hydroxyproline content and tenderness of ostrich meat were compared with goat meat to check quality parameter and result are showed in Table 3. Mineral content like calcium, phosphorous and zinc were determined as showed in Table 4. Sensory evaluation of ostrich and goat meat was determined by using hedonic scale as result mentioned in Table 5.

Table 2: Mean values for color of Ostrich and Goat Meat (Mean \pm SD), $n=3$

\begin{tabular}{cccc}
\hline Treatments & Color A* & Color B* & Color $\mathrm{L}^{*}$ \\
\hline Ostrich & $19.72 \pm 0.01$ & $14.24 \pm 0.01$ & $28.26 \pm 0.11$ \\
Goat & $15.04 \pm 0.02$ & $12.43 \pm 0.01$ & $48.31 \pm 0.01$ \\
\hline
\end{tabular}

Note $=$ color $\mathrm{a}^{*}$ show redness, color $\mathrm{b}^{*}$ show yellowness and color I* show lightness

Table 3: Mean values for color of Ostrich and Goat Meat (Mean \pm SD), $n=3$

\begin{tabular}{|c|c|c|}
\hline Parameters & Ostrich (Mean \pm SD) & Goat (Mean \pm SD) \\
\hline $\mathrm{pH}$ & $6.11 \pm 0.03$ & $6.15 \pm 0.04$ \\
\hline Cooking loss (\%) & $21.18 \pm 0.06$ & $28.16 \pm 1.07$ \\
\hline Drip loss (\%) & $2.84 \pm 0.01$ & $2.68 \pm 0.03$ \\
\hline Myoglobin (mg/g) & $1.14 \pm 0.02$ & $1.07 \pm 0.01$ \\
\hline Metmyoglobin (\%) & $33.15 \pm 0.08$ & $18.61 \pm 0.19$ \\
\hline Collagen content (mg/g) & $66.33 \pm 0.16$ & $32.73 \pm 0.08$ \\
\hline Hydroxyproline content & $9.31 \pm 0.05$ & $4.57 \pm 0.01$ \\
\hline Tenderness & $29.26 \pm 0.06$ & $45.98 \pm 0.09$ \\
\hline
\end{tabular}


Table 4: Mean values for mineral in Ostrich and Goat Meat (Mean \pm SD), $n=3$

\begin{tabular}{cccc}
\hline Treatments & Calcium & Phosphorus & Zinc \\
\hline Ostrich & $9.02 \pm 0.03$ & $216.63 \pm 0.68$ & $1.05 \pm 0.02$ \\
Goat & $11.12 \pm 0.04$ & $154.70 \pm 0.56$ & $3.48 \pm 0.01$ \\
\hline
\end{tabular}

Table 5: Mean values for color of Ostrich and Goat Meat (Mean \pm SD), $n=9$

\begin{tabular}{ccc}
\hline Parameters & Ostrich (Mean \pm SD) & Goat (Mean \pm SD) \\
\hline Appearance & $7.50 \pm 0.11$ & $7.34 \pm 0.12$ \\
Flavor & $6.80 \pm 0.05$ & $7.04 \pm 0.09$ \\
Tenderness & $7.17 \pm 0.06$ & $7.17 \pm 0.06$ \\
Juiciness & $7.38 \pm 0.12$ & $7.37 \pm 0.15$ \\
Overall acceptability & $7.02 \pm 0.01$ & $7.00 \pm 0.02$ \\
\hline
\end{tabular}

\section{DISCUSSION}

Proximate analysis- The results for compositional analysis of ostrich meat with respect to goat meat are mentioned in Table 1. Result represents the mean value of four parameters, which are ash, fat, moisture and protein. Results indicated that moisture content (76.51 \pm 0.05$)$ and crude protein $(21.18 \pm 0.06)$ was high in ostrich meat as compared to goat meat (75.71 \pm 0.01 , $20.04 \pm 0.13)$ respectively. Fat content in ostrich meat $(1.26 \pm 0.17)$ was low as compared to goat meat (3.23 \pm 0.05$)$. Similarly ash content was high in ostrich meat $(1.14 \pm 0.008)$ as compared to goat meat $(1.07 \pm 0.01)$ [19]. Fat content was more present in goat meat as compared to ostrich meat. Intra and inter muscular fat contain a rich source of energy but that fat deposit in body or in blood cause health problem, so consumer wants to eat low fat meat content.

Therefore, the above result indicated ostrich meat contains low fat content and is good for human health. Ostrich and goat are rich source of protein and more work in the body, maintain cell structure and regulate the function of tissue and organ and all enzyme activity by protein. Comparatively, ostrich meat is rich in ash, moisture and protein as compared to goat meat but both good for health ${ }^{[20]}$.

Quality analysis of ostrich and goat meat- $\mathrm{pH}$ is one, the basic parameter that is responsible for meat quality. Ostrich meat has less $\mathrm{pH}$ as compared to goat meat as measured during 24 hour post-slaughter.
Ostrich and goat meat $\mathrm{pH}$ on average falls between the range of 5.8 to $6.2^{[21]}$. $\mathrm{pH}$ is directly proportional to water holding capacity, as the $\mathrm{pH}$ increased that increased the water holding capacity of the meat and vice versa. The outcome with respect to investigating that ostrich and goat meat was fall between these categories as shown in Table 2. This $\mathrm{pH}$ range is ideal for ostrich and goat meat processing. There are different another factor that effects the $\mathrm{pH}$ of goat and ostrich meat that was slaughtering, deboning, bleeding, package and storage condition ${ }^{[22]}$. Color is one of the important characteristics of the meat because it is easily detected and selected by the consumer because it is most visible characteristic. The result showed that ostrich meat has color dark red to cherry red color as compared to goat meat. Outcome of this parameter has resemblance with Hoffman et al. ${ }^{[22]}$. Hoffman et al. ${ }^{[22]}$ investigated that $L^{*}$ value for ostrich meat follow in the range of 27.4 to 34.4 , a* value range from 11.7 to 20.4 and $b^{*}$ value from 6.0 to 9.3 so the result of study as mentioned below in mean value Table 3 to Table 5 but color $b^{*}$ show more color out of this range, this may be happened due to meat sample mincing and may be storage condition. The objective of water holding capacity of meat was to maintain water when applying any external forces during mincing, cutting and heating. Result indicates that cooking and drip loss are statistically were significant similarly more drip loss occur in ostrich meat as compared to goat meat as mention below in Table 3 . More cooking loss and drip loss occur in ostrich meat as 
compared to goat meat because ostrich meat is renderer as compared to goat meat, similarly having more moisture as compared to goat meat that why more cooking and drip loss occur in ostrich meat as compared to goat meat. The outcome of this study had resemblance with the Balog and Almeida ${ }^{[23]}$.

Meat color of ostrich and goat was due to the presence of myoglobin content. The result shows that ostrich meat had significantly more myoglobin content as compared to goat meat as mention below in Table 3 .

This is the basic reason that gives dark red to cherry red color to the ostrich meat as compared to goat meat. Myoglobin content varies in ostrich and goat meat, myoglobin content depends upon the age, sex and muscles. On the other hand, metmyoglobin is an indicator of color deterioration Joseph et al. ${ }^{[24]}$. Result found has close resemblance with Joseph et al. ${ }^{[24]}$ indicated that metmyoglobin is an indicator of color deterioration. Collagen content is the main protein that influences the tenderness of the meat. There are more research has been conducted on collagen content but contradictory are present on the result of collagen content because different researcher shows different result ${ }^{[16]}$. Therefore, it is understood cross-linkage in the connective tissue increased as the age of animal increased and that cross-linkage of connective tissue stable at a later stage. It is also noteworthy that as a younger animal has more connective tissue as compared to older animal and tenderness of meat occur due to cross-linkage ${ }^{[25]}$. The result of the study that shows in Table 3, that ostrich meat has more collagen and hydroxyproline content as compared to goat meat. The result shows that ostrich meat statistically more significant as compared to goat meat.

Tenderness is also a basic parameter of the meat quality and gain attention of the consumer either it should be acceptable or not. Tenderness is an appreciated property due to its collagen to protein ratio and low level of fat content. This trait is responsible for easiness in chewing, digestibility and also responsible for meat texture. The result indicates that ostrich meat was softer and having more tenderness as compared to goat meat because ostrich meat required low force as compared to goat meat as mentioned in Table 3. The result gained had close assessed to the Sales and Hayes ${ }^{[16]}$. Outcomes also had close resemblance with the Balog ${ }^{[26]}$. Meat was considered a rich source of mineral and protein in the human diet especially iron, zinc, calcium and phosphorous. The result of the study shown, ostrich meat contains the high amount of phosphorous as compared to goat meat as shown in Table 4. Similarly calcium was more in the goat meat as compared to ostrich meat. Results are mention below in Table 4. Zinc content was also more in goat meat as compared to ostrich meat as result mentioned in Table 4. The result of my study had close resemblance with the Meilgaard et al. ${ }^{[16]}$ also resemblance with Dhanda et al. ${ }^{[6]}$.

\section{CONCLUSIONS}

Our results indicated that ostrich meat was more acceptable as compared to goat meat. Result showed, ostrich meat contain more moisture, high protein as compared to goat meat and low fat as compared to goat meat. So it would be recommended for those consumer that having high cholesterol, cardiovascular diseases and other such diseases. Ostrich meat was overall good for everyone, good for health without any life threatening. In future, ostrich meat would be used as a staple meat and especially used for those patients that have the cardiovascular disease because ostrich meat has a less fat percentage as compared to goat meat. One drawback is that in market, ostrich meat is expensive as compared to goat meat in Pakistan.

\section{ACKNOWLEDGMENTS}

The authors are grateful to Associate Professor Dr. Muhammad Issa Khan for valuable comments to the manuscript.

\section{CONTRIBUTION OF AUTHORS}

Research concept- Muhammad Issa Khan, Muhammad Bilal Akram

Research design- Muhammad Issa Khan, Muhammad Bilal Akram

Supervision- Muhammad Issa Khan

Materials- Muhammad Issa Khan, Muhammad Bilal Akram

Data collection- Muhammad Bilal Akram, Shahiryar Khlid Data analysis- Muhammad Bilal Akram

Literature search- Muhammad Bilal Akram, Muhammad Shoaib

Writing article- Muhammad Bilal Akram

Critical review- Muhammad Issa Khan

Article editing- Muhammad Bilal Akram

Final approval- Muhammad Issa Khan 


\section{REFERENCES}

[1] Government of Pakistan (GOP). Economic survey of Pakistan, Ministry of finance, Government of Pakistan, 2017.

[2] Anderson EW, Shugan S. Repositioning for changing preferences: the case of beef versus poultry. J Consum. Res., 1991; 18(2): 219-32.

[3] Alexander RMN, Maloiy GMO, Njau R, Jayes AS. Mechanics of running of the ostrich (Struthio camelus). J. Zool., 2009; 187(2): 169-78.

[4] Hoffman LC, Muller M, Cloete SWP, Brand M. Physical and sensory meat quality of South African Black ostriches (Struthio camelus var. domesticus), Zimbabwean Blue ostriches (Struthio camelus australis) and their hybrid. Meat Sci., 2008; 79(2): 365-74.

[5] Anaeto M, Adeyeye JA, Chioma GO, Olarinmoye AO, Tayo GO. Goat products: Meeting the challenges of human health and nutrition. ABJNA, 2011; 1(6): 1231-36.

[6] Dhanda JS, Taylor DG, Murray PJ, McCosker JE. The influence of goat genotype on the production of Capretto and Chevon carcasses. Meat Sci., 1999; 52(4): 363-67.

[7] Pena FA, Bonvillani B, Freire M, Perea J, Gómez G. Effect of breed and slaughter weight on the meat quality of Criollo Cordobes and Anglo nubuian kid produced under extensive feeding condition. Meat Sci., 2009; 83(3): 417-22.

[8] Bossman HG, Moll HAJ, Udo HMJ. Measuring and interpreting the benefits of goat keeping in tropical farm systems. Agric. Syst., 2002; 53: 349-72.

[9] Association of Official Analytical Chemists (AOAC). The Official Method of Analysis of AOAC International. $18^{\text {th }}$ ed. Arlington, USA, 2005.

[10]Berge P, Lepetit J, Renerre M, Touraille C. Meat quality traits in the Emu (Dromaius novaehollandiae) as affected by muscle type and animal age. Meat Sci., 1997; 45(2): 209-21.

[11]Hunt MC, Acton JC, Benedict RC, Calkins CR, Cornforth DP, et al. Guidelines for meat color evaluation. $3^{\text {rd }}$ Ed., Chicago; American Meat Science Association and National Live Stock and Meat Board, 1991.

[12]Honikel KO. Reference methods for the assessment of physical characteristics of meat. Meat Sci., 1998; 49(4): 447-57.
[13]Trout GR. Techniques for measuring water binding capacity in muscle foods- A review of Methodology. Meat Sci., 1989; 23(4): 235-52.

[14]Naveena BM, Mendirartta SK, Anjaneyulu ASK. Tenderization of buffalo meat using plant proteases from Cucumis trigonus Roxb. and Zingiber oficinale roscoe. Meat Sci., 2004; 68(3): 363-69.

[15]Piga A, Catzeddu P, Farris S, Roggio T, Sanguinetti A, et al. 2005. Texture evolution of 'Amaretti' cookies during storage. Eur. Food Res. Techno., 221(3): 38791.

[16]Sales J, Hayes JP. Proximate, amino acid, mineral composition of ostrich meat. Food Chemistry, 1996; 56(2): 167-70.

[17]Meilgaard MC, Civille GV, Carr BT. Sensory Evaluation Techniques. $4^{\text {th }}$ Ed., NY, USA; CRC Press, 2007.

[18]Steel RGD, Torrie JH, Dickey D. Principals and Procedures of Statistics: A biometrical approach. $3^{\text {rd }}$ Ed. Mc Graw Hill Book Co. Inco. NY, USA, 1997.

[19]Pegg R, Amarowicz R, Code WC. Nutritional characteristics of emu (Dromaius novaehollandiae) meat and its value-added products. Food Chem., 2006; 97(2): 193-202.

[20]Horbanczuk JO, Sales J. Lipid and cholesterol content and fatty acid composition of meat obtained from ostriches reared on a commercial farm. Anim. Sci. Pap. Rep., 1998; 16(1): 51-55.

[21]Majewska D, Jakubowska M, Ligocki M, Tarasewicz Z, Szczerbin D, et al. Physicochemical characteristics, proximate analysis and mineral composition of ostrich meat as influenced by muscle. Food Chem., 2009; 117(2): 207-11.

[22]Hoffman LC, Muller M, Cloete SWP, Brand $M$. Physical and sensory meat quality of South African Black ostriches (Struthio camelus var. domesticus), Zimbabwean Blue ostriches (Struthio camelus australis) and their hybrid. Meat Sci., 2008; 79(2): 365-74.

[23]Balog A, Almeida PICL. Ostrich (Struthio camelus) carcass yield and meat quality parameters. Braz, J. poultry Sci., 2007; 9(4): 215-20.

[24]Joseph P, Suman SP, Beach CM, Steinke L, Fontaine M. Characterization of bison (Bison bison) myoglobin. Meat Sci., 2010; 84(1): 71-78. 
[25]Price JF, Schweigert BS. The nutritional content and value of meat and meat products. In The Science of Meat and Meat Products. $4^{\text {th }}$ Ed., Inc., Westport, CT, USA, Food and Nutrition Press: 1987; pp. 275.

[26]Balog A. Ostrich (Struthio camelus) carcass yield and meat quality parameters. Braz. J. Poultry Sci., 2007; 9(4): 215-20.

[27]Berge $P$, Lepetit J, Renerre $M$, Touraille C. Meat quality traits in the emu (Dromaius novaehollandiae) as affected by muscle type and animal age. Meat Sci., 1997; 45(2): 209-21.
[28]Marks J, Stadelman W, Linton R, Schemieder H, Adams R. Tenderness analysis and consumer sensory evaluation of ostrich meat from different muscles and different aging times. J. Food Quality, 1998; 21(5): 369-81.

[29]Holzer Z, Berry BW, Campbel AM, Spanier MA. Effect of koshering and hydronynamic pressure on beef color, odor, and microbial loads. J. Muscle Foods. 2004; 15(1): 69-82.

[30]Agbeniga B, Webb EC, Neil HAO. Influence of kosher (shechita) and conventional slaughter techniques on shear force, drip and cooking loss of beef. S. Afr. J. Anim. Sci., 2013; 43(5): 98-102. 